\title{
ЈЕЗИК И ЈЕЗИЦИ ОБРАЗОВАЊА ${ }^{1}$
}

\section{Сажетак}

Савремене језичке политике промовишу више нових погледа на значај језика у образовним системима, као и на различите облике наставе у оквиру вишејезичности као промовисаног приступа. Настава српског језика, на пример, посматра се ограничено, у оквиру самосталног предмета, а никада као основно и специфично средство у језику образовања, у функцији постизања академске језичке компетенције српског као вехикуларног језика на коме се одвија највећи проценат наставе из свих осталих предмета у школском систему. Такође, настава страних језика не посматра се као извор заједничких компетенција које доприносе богаћењу како енциклопедијских знања, тако и језика појединца као изражајног средства, који равноправно учествују у формирању језика образовања и као саставне компоненте чине језик свакодневне комуникације и посебне академске компетенције језика образовања.

У овом раду, на основу увида у глобализацијске процесе и специфичности европске језичке политике који се рефлектују на језичке образовне политике савременог вишејезичног друштва, подвлачи се значај језика̂ у савременим образовним системима и потреба креирања језичке образовне политике одоздо-на-горе у којој се пресликавају глобално признате језичке образовне потребе на локалном плану.

Кључне речи: језичке политике, језик и образовни системи, језик и језици образовања, страни језик, други страни језик.

\section{Увод}

Питања језика у образовним системима често се ограничавају на површне, недовољно јасне, чак и политички манипулисане декларативне поруке, подржане недовољно стручним медијским ангажманом,

1 Овај рад израђен је у оквиру пројекта Динамика структура српског језика, 178014 , који финансира Министарство просвете, науке и технолошког развоја Републике Србије. 
али и теоријски неподржаним изјавама представника академских институција о улози и значају језика̂ (матерњих и страних) у образовном систему Републике Србије. Често се воде дискусије о значају матерњих језика за национални идентитет, проблеми се усмеравају у највећој мери на разговоре и декларације о очувању националног писма, противљењу увођењу страних речи у савремени језик, затим уверавања да су права националних мањина на школовање на матерњем језику задовољена, de iure, њиховим местом у законским актима, а не и применом, да за грађане који припадају већинској популацији није потребно увести обавезу учења мањинског језика средине, да двојезично образовање може да штети и једнима и другима, припадницима већинске или мањинске популације, да се матерњи језик не може изучавати осим традиционалним начином путем књижевности често на језику далеком и слабо разумљивом генерацијама који наставу прате чак и у раном школском узрасту, да се језик учи формалистичким посредовањем знања о језику, да учење страних језика генерално угрожава усвајање матерњег језика и да има штетне последице на исправну употребу истог као и на формирање националног идентитета, да су питања учења и наставе страних језика решена тиме што су они заступљени без обзира на квалитет њихове наставе изражен кроз избор језика, број часова, број ученика, али уз уверење да их у наставу треба што касније увести, да други страни језик, без обзира на његов значај, треба маргинализовати кроз програмску изборност, необавезу бројчаног оцењивања, и на паушалне и неозбиљне процене да, уосталом, страни језик нико није научио у школи итд. Праве стратегије везане за наставу језика̂ у образовном систему Републике Србије нема.

Из низа набројаних, тек неких од честих питања, која се тичу језичких образовних политика, може се приметити да су она заснована на дубоком непознавању материје, или на стихијском одлучивању, примени појединачног и посебног на цео систем, праћењу помодних трендова или само делимичном познавању неких модела и њиховом увођењу у неприпремљени оквир, без сагледавања глобалног контекста, склопа образовних система у који је смештен организам школског система Републике Србије, али и на одлукама које се доносе или су донесене брзоплето, без увида у последице које из њих, као ланчана реакција проистичу, повлачећи са собом све учеснике у систему ученике, наставнике, неусклађене нивое школовања, институције које школују наставнике итд. 
Језици у образовном систему и њихова усклађеност и значај, једна су од важних тема дискусија и акција у образовним системима света. Улагања у наставу језика, а посебно страних језика, којим руководе владе или образовне институције, као и бројне организације приватног сектора, захтевају систематску анализу ${ }^{2}$ који су то језици чије ће учење донети највеће предностси појединцима, друштву у најширем смислу и економији земље.

\section{Систем језика одоздо-на-горе, према локалним потребама}

Неки језици преузимају доминантан положај у односу на друге помоћу афирмације снаге и моћи својих говорника. Ако је некада та моћ била изражена војном снагом, у наредним фазама моћ језика преносила се војном надмоћи, да би се у данашње време, сасвим јасно препознала у економској доминацији. Такав је случај и са доминантним језиком доба у коме живимо. Језик који најчешће служи за споразумевање у савременом свету је без сваке сумње енглески ${ }^{3}$. Иако није први ${ }^{4}$, већ други или трећи по бројности говорника, иза

2 Као пример озбиљног приступа и опредељења за стратешки промишљен, заснован на потребама, одоздо-на-горе постављен избор страних језика, служи искуство Велике Британије изнесено у анализи рађеној 2014. године за потребе британског образовног система, (Линк 1), где су приказани језици који ће овој земљи бити потребни у наредних 10 - 20 година.

3 Према подацима из извештаја Европске комисије објављеног маја 2017. године, у скоро свим земљама Европе највећи број ученика учи енглески језик током обавезног основног и средњег образовања. (Европска Комисија / EACEA/Eurydice, 2017:13).

4 Према подацима из 2014 (Линк 1), на првом месту је мандарински кинески са 955 милиона говорника матерњег језика, нематерњег 194 милона, широко распрострањен у Кини, Тајвану и Сингапуру. На другом месту је Енглески са 360 милиона говорника матерњег језика, 603 нематерњег, широко распрострањен у свету. Енглески дугује своју широку распрострањеност у свету присуством у економски најутицајнијим земљама. То је најупотребљаванији језик на интернету. Број нематерњих говорника енглеског језика је у непрестаном порасту. Треће место заузима шпански са 427 милиона говорника матерњег језика и 91 милионом нематерњих говорника. 
кинеског и шпанског (Кристал, 2008), у свим својим облицима, служи за брзо, практично, пословно и дипломатско споразумевање, заузимајући место некадашњег неоствареног сна о вештачким (помоћним) језицима за глобално споразумевање - Идо, Интерлингуа, Есперанто 5 (Вучо, 2009a). Посматрајући светску језичку сцену можемо закључити да није само енглески доминантан језик данашњице. Опредељење за економски просперитет коинцидира са прихватањем нове култуpe, а потреба идентификације са језиком постаје све слабија услед тежње грађана да прошире свој простор деловања (Фишман, 1991, 2001). У зависности од перспективе из које се посматра одговарајући ареал, постојање великих језика који угрожавају мање или мање јаке присутно је у Русији, Африци, на Средњем Истоку, у Кини, Индији и у Јужној Америци. За језички хегемонизам оптужени су: руски, енглески, арапски, кинески, хинду, португалски, шпански (Вучо, 2009). Сличне појаве јављају се и код мањинских језика у вишејезичним срединама, где се говорници мањинских језика свесно опредељују за школовање на већинском, националном језику (нпр. словачки у Сpбији, Филиповић, 2009), док се истовемено спроводе брижне акције за очување мањинских језика.

Међутим, није само економски критеријум битна одредница избора језика за комуникацију или језика који ће се користити у образовним системима. Почетком овог века јавља се појам Језичко тржиште (Жан Луј Калве, 1999) који подразумева систем у оквиру кога се језици распростиру међу потенцијалним корисницима на међуна-

5 Огољени, практични, испражњен од културних и цивилизацијских садржаја, енглески језик, дефинисан је различитим терминима у научној комуникацији, заснованим на ставовима језичке екологије, социолингвистике, примењене лингвистике, методике наставе, ЕЛТ, СЛА, језичке политике и планирања, итд: енглески као средство међународне комуникације (Мајеркорд, 1996), глобални (Кристал, 1997, 2000), међународни (Џенкинс, 1998, 2001), енглески као светски језик (Мер, 2003), интернационални (Зајдхоферова, 2003). Сасвим се уврежио термин енглески као lingua franca који се употребљава и изван стручних кругова. Сви ови термини означавају језик изведен из уобичајеног тока, који излази из оквира обичног језика и осваја необичну позицију језика који је потиснуо са сцене модел „говорника матерњег језика““ (Амон, 2000, Филиповић, 2008). 
родном плану на основу своје утрошивости. Чине га разноврсни фактори који се не односе искључиво на економску сферу интересовања. Позиција неког језика у широкој перспективи зависиће од његовог унутрашњег идентитета, семиотичког идентитета језика, друштвене и продуктивне динамике заједнице која се прелива у језик, образовне политике и промоције дифузије језика, способности друштва да понуди сопствени идентитет који је формиран и понуђен кроз успешне и престижне моделе. Овако посматран проблем распрострањености језика и њиховог присуства показује да не постоје неутрални процеси у дифузији језика на међународном плану. Језичко тржиште зависи, дакле, и од лингвистичких и екстралингвистичких фактора, а способност привлачности неког језика је мера вредности неког друштва у перцепцији странца ${ }^{6}$.

Да поменути критеријуми Калвеове језичке утрошивости, мере коју поседује сваки језик на светском језичком тржишту нису јединствени, показује пример озбиљног аналитичког преиспитивања потреба британског образовног система, којим се подразумева да се избор језика̂ у које треба улагати у формалној и неформалној настави заснива како на економским тако и неекономским критеријумима. Истиче се да се језици потребни некој средини из економских разлога не подударају са онима које треба неговати да би се изградило поверење, продубио међународни утицај и учврстили културни односи као и безбедност земље (Линк 1, 6). У овој студији Британског савета подвлачи се да постоје три области са десет фактора који утучу на избор приоритетних језика у неком систему: I. економски, у које спадају сазнања о 1. извозним привредним дестинацијама, 2. језицима неопходним за

6 Као пример за специфична кретања вредности на језичком тржишту може да послужи стабилна позиција италијанског језика. Иако се не налази у врху језика по броју говорника (међу 20 је језика са највећим бројем говорника, са око 64 милиона говорника матерњег и нематерњег, види Линк 3), италијански језик је пети у свету међу најпривлачнијим језицима за учење. Интересовање за италијански језик и његова вредност на језичком тржишту потичу управо од фактора који се односе пре свега на друштвене и продуктивне динамике италијанске заједнице, која се преноси на језик и способности италијанског друштва да понуди сопствени идентитет, формиран кроз успешне и престижне моделе, док се у мањој мери ослања на промоцију дифузије језика. 
пословне потребе, 3. владиним будућим трговинским приоритетима и 4. новим растућим тржиштима; II културни, обазовни и дипломатски фактори који се односе на 5. дипломатске и безбедносне приоритете и 6. језике од јавног интереса,7. одлазне и долазне туристичке токове, 8. владине међународне образовне стратегије и приоритете; III фактори равнотеже који обухватају 9. нивое владања енглеским језиком у другим земљама и 10. присутност различитих језика на интернету. У зависности и усклађености свих ових варијабли успоставља се мрежа језика од приоритетног значаја за будућност земље , с намером да у постојећи систем учења страних језика укључи шири број језика и отвори могућности да разноврсне и потребне, одоздо-на-горе, према суштинским потребама одабране језике учи што већи број грађана.

\section{Језичка политика Европе}

Са новом свешћу о равноправности свих чинилаца, а сходно томе и језика и култура унутар мултинационалних држава, са новим миграционим динамикама, мобилношћу савременог глобалистичког или већ постглобалистилчког света, јавља се и јасно профилисана потреба за дефинисаним, стабилним и стандардизованим знањима језика̂. Потреба за језичком равноправношћу и функционалношћу испољава се у свим доменима друштвене стварности, пословној, академској, приватној итд.

У Европи, значај језицима дају прокламовани ставови политике Европске заједнице који се заснивају на подржавању и потврђеном промовисању плурилингвизма, мултикултурности и једнакости свих језика Заједнице. Једна од основних вредности ових опредељења јесте посвећеност развијању плурилингвизма, схваћеног као способност комуникације појединца и заједнице на више језика, са различитим квалитетом нивоа знања, као и подстицање стварања системских и континуираних прилика за целоживотно усавршавање и учење свих језика (Този, 2007, Баеко и др. 2009,). Сваки грађанин има право да говори својим језиком и да учи друге језике по свом избору. Могућност слободног остваривања тог права један је од основних захтева за 
лични и каријерни напредак, мобилност људи и идеја, за подстицање дијалога, толеранције, разумевања и узајамног обогаћивања народа и култура. Уз то се подвлачи да је од изузетног значаја способност комуникације на језицима различитим од матерњег како би се одговорило на културне, економске и друштвене промене у Европи ${ }^{7}$. Наглашена потреба за знањем страних језика не издваја нити један од двадесет четири језика европске економске и политичке заједнице, већ се сматра да језици треба да су одабрани према географским (који укључују и историјске и културне) и економским критеријумима, прокламујући глокални приступ као једини прихваћени и подржавани избор (Вучо, 2009, Филиповић 2009, Филиповић, Вучо, Ђурић 2010, Филиповић \& Вучо, 2012, Филиповић, 2012, 2015, 2016). Језичка различитост ${ }^{8}$ види се и у њеним бројним облицима, заштити мањинских (често угрожених) језика, до предности која се даје учењу језика суседа и суседних култура као и свих осталих језика Европе пред глобализацијским про-

7 У прогласу промовисаном од стране групе интелектуалаца предвођене Хуаном Мануелом Барозом 2008. године (Барозо ет ал. 2008), којим се потврђују ставови европске језичке политике и подржава плурилингвизам као основна вредност заједнице, указује се на три језика које треба да поседује сваки појединац и који налазе своје место у оквиру образовних система држава Заједнице: језик за идентификацију, најчешће матерњи језик, језик глобалне/ међународне, континенталне комуникације (најчешће енглески, али и неки други језик глобалног обухвата као што су шпански, француски, кинески, португалски, или неки други), и лични усвојени језик који би у образовним системима, на свим нивоима, требало развијати до највиших способности појединаца, као други матерњи језик. Избор личног усвојеног језика зависи од разних фактора, не може се наметати на нивоу заједнице или бити истоветан за све грађане једне државе: то може бити, на пример, већински језик за имигрантску популацију, мањински језик за мигрантску популацију рођену у дијаспори, али и неки од, такозваних, признатих, великих “светских” језика. Овај језик зависи и од професије појединца, не мора се изабрати у раном детињству, може бити регионални, мањински или језик неке од суседних држава који је потребан појединцу у контактима различитих намена.

8 „Језичка различитост је део европског ДНК. Обухвата не само званичне језике земаља чланица ЕУ, већ и регионалне и/или мањинске језике који се столећима говоре на територији Европе, као и језици које су са собом донели различити таласи миграната. Коегзистенција тих различитих језика за Европу представља како предност тако и изазов.“ Европска Комисија, 2017:9. 
цесима. Европске језичке политике имају за циљ охрабривање културних и језичких разлика и промовисање интеграције мањина и имиграната ${ }^{9}$, друштвену кохезију и поштовање људских права (Линк 2).

О трајној актуелности овакве европске језичке политике у прилог иду и промене изазване таласима миграната и радне снаге који настављају живот у новом окружењу другог, језика са свим социјалним, културним, образовним и осталим потребама укључивања њих самих и њихових породица у нови живот и свет рада. Европско друштво јесте с једне стране вишејезично ${ }^{10}$, а са друге стране, индивидуална вишејезичност у Европи се сматра најважнијим условом за миран заједнички живот разних народа ${ }^{11}$.

До остваривања овог концепта долази се развијањем посебне стратегије која се усмерава ка осмишљеној и планираној, а не стихијској, језичкој образовној политици (Филиповић, Вучо, Ђурић, 2008, Филиповић \& Вучо, 2012, Филиповић, 2012, 2015, 2016, Ђуриц, 2016) заснованој на потребама ${ }^{12}$, адекватним моделима наставе

9 О новој улози српског језика у оквиру савремених токова мигрантске кризе више у Вучо, Јулијана, Ђурић, Љиљана Крајишник, Весна, Стрижак, Никица, Сукновић, Мина, Филиповић, Јелена (2017) Од српског као страног језика до српског као језика окружења и образовања: оквир програма језичке подршке, Филолошки факултет Универзитета у Београду, Београд.

10 Вишејезичност, модел јединствене и правичне потребе у савременој Европи и свету, развио се из расправа вођених седамдесетих година, чији су исход биле Хомбуршке препоруке из 1980. (Рутке, 2002:97-100) које се чврсто држе идеје о вишејезичном друштву.

11 Теоријска истраживања и емпиријска искуства великог броја образовних институција широм света јасно указују да је учење других језика вишеструко корисно: унапређује опште когнитивне способности ученика, унапређује општа академска постигнућа, ствара појединце отворене и толерантне према новим и другачијим културама и традицијама, спремне да слободно ступају у контакт са говорницима других.

12 Иако је увек присутна бојазан да глобализацијске тенденције могу да угрозе потребе грађана на индивидуалном и локалном плану, да се идентификују са својом државом, религијом, културним специфичностима итд, изваја се решење које увек треба засновати на актуелном ставу ираженом кроз појам глокализације којим се повезује отвореност према светским токовима, истовремено са усмерењем на јаку локалну и регионалну припадност као и планирање и имплементацију засноване на потребама средине, одоздо-на-горе. 
мањинских језика, променом традиционалних (непланираних) начина избора страних језика у школама, издиференцираним циљевима учења у настави страних језика (првог и другог), са адекватним суштинским променама у поимању улоге и повезаности матерњих и осталих језика у настави, истицањем матерњих (укључујући и мањинске) и страних језика као посредним, вехикуларним језицима, инструменатима на којима се обавља настава нејезичких предмета итд. ${ }^{13}$.

\section{Језици за целоживотно учење}

Са циљем да подстакне владе ЕУ да наставу и учење кључних компетеција учине делом стратегија за целоживотно учење, Европски парламент је донео препоруку којом се указује на осам кључних компетенција од основног значаја за сваког појединца у друштву заснованом на знању (Линк 4). Осам узајамно зависних кључних компетенција односе се на стицање основних знања, вештине и ставове од суштинске важности за целоживотно учење наглашавају критичко мишљење, креативност, иницијативу, решавање проблема, процену ризика, доношење одлука и конструктивно управљање осећањима. Кључне компетенције за будућност грађана су: 1. комуникацја на матерњем језику, 2. комуникација на страним језицима, 3. математичка компетенција

13 Језици се не могу посматрати као непромењива датост. Диксон (1997) сматра да језици стварају своје нове просторе, пратећи кретање популације, или боље речено, премештају се из једне области у другу успостављајући институције цивилног друштва које су у стању да их подрже и одрже. Диксон успоставља разлику између спонтаних и привремених миграција језика и њихове трајне експанзије која се у историји јавила током колонијалних доминација. Диксонов став прихватамо и усмеравамо ка неопхдним интервенцијама државе на пољу одржавања и бриге о језицима са малим бројем говорника као што је српски (Вучо 2007а, Вучо 2008б). Миграције стотина хиљада становника започете токм ратова дведесетих (Гудељ, 2006, Вучо, 2007a), настављене подстакнуте економском изнудицом и жељом за бољим животом и могућностима професионалног развоја, нису донеле никакав бољитак статусу српског језика, штавише, довеле су до укидања готово свих лектората, занемаривања дифузије српског језиак у свету, неадекватне бриге за децу исељеника, као и за систем прихвата повратника, репатрираних и расељених лица. 
и основне компетенције у науци и технологији, 4. дигитална компетенција, 5. учење како се учи, 6. друштвене и грађанске компетенције, 7. смисао за за иницијативу и предузетништво и 8. културна свест и изражавање ${ }^{14}$. Овде обраћамо посебну пажњу да су прве две компетенције оне које се тичу језика̂, матерњег и страних.

\section{Језици образовања}

Обавеза вишејезичног језичког образовања припада школи као базичној институцији модерних друштава. Језичка политика у едукативним системима израз је политике оспособљавања, социјалне инклузује, развијања самосталног учења и демократског мишљења грађана, за добробит појединаца и заједница у којима живе. Језичко образовање је део политике усмерене ка развијању друштвене кохезије.

Овакве стратешке одлуке изазвале су бурну активност: укључен је велики број посленика из свих средина, произведен је низ докумената, нових инструмената и препорука који могу да помогну у реализацији става да језичко образовање и образовне политике не могу да буду раздвојене од социјалне оријентације усмерене ка друству знања (Линк 4). Баеко и др. 2009 упућују на холистичко поимање језика̂ и језичко планирање током обавезног школовања. Језици школовања обухватају не само матерњи језик, већ све језике који се уче у школи, 1. матерњи, страни, класични, нематерњи, мањински или регионални језик, као предмет, 2. језике који се користе као средство, вехикуларни језик (језик посредник), за наставу и учење других предмета, а то су језици наставног програма (матерњи, страни, ласични, мањински или регионални, нематерњи). Језике школовања, образовања чине дакле сви језици које ученик среће током школовања као део интегрисаног језичког курикулума (Вучо, 2009б, 2009ц) . Такав, холистички начин поимања језичког образовања осим што одговара на предности уоптребе заједничких језичких карактеристика и узајамну примену вишеструких језичких искустава на све језике укључене у наставу,

14 Ове потребе поновљене су 2009. и 2014. године у новим стратешким програмима до 2020. Упућујући на важност остваривања стратегија целоживотног учење и мобилности. 
одговара и прокламованим савременим изазовима вишејезичности, потребе за плурилингвалним и интеркултурним компетенцијама које пружају могућности ученицима да у образовном процесу стекну језичке и интеркултурне компетенције које ће их оспособити да са успехом делују као грађани, да усвајају знања и да развијају отворене ставове према другоме и другости.

Овакав приступ погодује свим језицима у језички сложеном образовном систему.

\section{Академски језик, језик образовања}

Академским језиком сматра се онај регистар језика који се користи у процесу образовања, у различитим образовним околностима, у учионици и ван ње, у уџбеницима и осталим наставним материјалима свих предмета на језицима образовања, то је језик инструмената за проверу знања, језик тестова, испита, налога сваке врсте за проверу знања свих нејезичких и језичких садржаја и предмета, нивоа језичке компетенције свих језика укључених у образовни процес итд. (Вучо, 2009б, 2009ц) Обухвата академско читање, слушање, говор, писање, информатичку писменост, истраживачке вештине, вештине излагања и формулисања испитних садржаја, развоја академског речника, итд. Ова знања и вештине су међусобно повезане и међусобно се допуњују и преплићу, те се не могу посматрати изоловано (Вучо, 2009ц).

Академски језик, током школовања на свим узрастима, од најнижег до одраслог, подразумева нпр. разликовање битних од небитних информација у тексту, сажмање или преформулацију информација на основу прочитаног, резимирање, парафразирање и синтетизовање, повезивање текста са претходним садржајима, прављење белешки у вези са текстом, препознавање или продукцију адекватне афиксације, препознавање текстуалних сигнала као што су нпр. масна, болдована слова, курзив и слично. Вештина слушања за академске потребе подразумева нпр. развијање низа умења везаних за слушање академских садржаја, препознавање стила предавања, познавање структуре академског говора и развој пратећих вештина израде бележака, скица 
текста, садржаја, препозавања неформалног академског језика, разумевања садржаја предавања без обзира на брзину, боју гласа, артикулацију говорника. Академски говор подразумева нпр. низ посебних вештина и знања међу којима су и припрема и извођење предавања, дискусија, семинара, усмених презентација, вербализовање података добијених из различитих врста текста, итд. Академски језик подразумева и владање академском информатичком писменошћу, односно обраду и презентовање усвојеног и истраженог уз помоћ савремених средстава, коришћење база података, онлајн речника, репозиторијума, повезивање са наставником и осталим учесницима у наставном процесу путем платформи, академске испитне вештине које се односе на анализу усвојених садржаја предмета и могућих испитних питања, вештину припреме писмених и усмених одговора, познавање врсте тестова и задатака, вештину ревизије, перформативне вештине, итд. Академски језик подразумева познавање језика специфичног академског метајезика, коришћење специфичних врста како линеарног текста (континуираног), различитих врста текстова (нарација, дескрипција, излагања, аргументација, упутстава, докумената, хипертекста), тако и нелинеарног (неконтинуираног) текста, као што су табеле, графикони, схеме, дијаграми, мапе, формулари, рекламе, сертификати, итд.

Структура академског језика не подудара се са оном језика свакодневне комуникације, као што ни подразумевано знање матерњег језика (оличено у уверењу да сваки матерњи говорник неког језика може да га без сметњи користи у свим приликама), неће значити да ће ученик бити успешан у коришћењу академског језика и сналажењу у школско-академском контексту. Бројна су истраживања језичких постигнућа ученика, као и њиховог академског постигнућа, која академски успех ученика недвосмислено доводе у везу са развијеним вештинама академског језика. Ова истраживања указују на две категорије језичких компетенција: основну, BICS, Basic Interpersonal Communication Skils - Основне интерперсоналне комуникативне вештине, и академску компетнецију, CALP, Cognitive Academic Language Proficiency - Когнитивна академска језичка способност (Каминс, 1982, 1999, 2010). Говорећи о овим компетенцијама код ученика Л2 истичу се различите временске периоде потребне за савладавање ове две 
компетенције: за основну компетенцију довољне су две године, док се академска стиче од 5 до 7 година. Прва се односи на способности комуникације у свакодневном општењу, изван образовног конткста, док се друга, когнитивно сложенија и захтевнија, повезује са знањем функционалних стилова, секторских језика, по лингвистичким карактеристикама које је обележавају као што су у енглеском језику нпр. дуже реченице, сложене номиналне групе, честа употреба пасива итд. Свему овоме додаје се и сложеност израза која се огледа у лексичкој сложености.

Основна разлика између две категорије језичких знања је у томе што базична компетенција укључује и контекст (употребу екстралингвистичких и паралингвистичких средстава као што су покрет, или могућност парафразирања, риелаборације и понављања језичке поруке), док језичка компетенција за академске потребе располаже редукованим контекстом. Улога односних језичких регистара (посебних терминологија везаних за појединачне предмете, нпр. математику, физику, хемију, уметност, историју и сл., формални стил, граматичке структуре и паратакса, употреба интернационализама и латинизама итд.) има посебну вредност у академском метајезику.

Тешкоће на које ученици наилазе могу се довести у везу са језичким захтевима задатака у наставном и образовном процесу, и неприлагођеношћу ученика на структурисање дискурса који их у том процесу очекује. Анализовање језичких проблема веома је битан корак у решавању проблема неуспешности у академском постигнућу како за говорнике матерњег, тако и за оне којима наставни језик није матерњи јер се ради о језику који је примарно средство комуникације. Изазови којима се ови говорници излажу налазе се и у неадекватном језику уџбеника и осталог наставног материјала. Сматра се да језик образовања треба посматрати са становишта више лингвистичких дисциплина, социолингвистике, анализе дискурса и примењене линвистике. Тумачења до којих ће се доћи помоћу тих различитих лингвистичких виђења треба усредсредити на јасну функционалну језичку перспективу.

У свакодневној и образовној пракси ученици користе речи које већ познају и умеју да користе на прикладан начин. Ради се о јез- 
гру које може да садржи и неке необичне изборе, неке речи које су веома ретке, неке које су биле популарне јер су се појавиле у некој игри, игрици, песми или телевизијској емисији, а с друге стране. Такође, неке речи које сматрамо основним у матерњем језику ученици не схватају најбоље, или их уопште не поседују у свом репертоару, не знају ни њихов акценат, граматичку или синтаксичку употребу.

Једна од основних препрека у разумевању и продукцији било каквог академског текста јесте веома низак ниво квалитета академског речника ученика. Познавање и контрола академског речника или недостатак познавања лексема специфичних за образовне потребе, препознаје се као један од кључних дискриминатора у процесу школовања. Академски вокабулар је неопходна компонента у успешној примени вештина академског читања, говора и писања и, будући да је саставни део академског језика, у непосредној је вези са успехом током школовања, а касније и са економским могућностима и друштвеним благостањем појединца (Шорт \& Спанос, 1989, Коксхед, 2000, Шлепегрел, 2004, Волемер, 2006, Лазаревић 2011, Вучо 2009б, 2009ц).

Развијање речника матерњег и свих осталих језика школовања, усвајање речника, ширење семантичких поља, подучавање за самостално коришћење речника, уочавање и коришћење адекватних конкорданци, само су неке од вештина и знања својствених академском језику.

Као пример одговорног односа према прогрсивном усвајању академске лексике могу да послуже неки од бројних примера специјализованих листа речи према школским предметима и нивоима-разредима.

\section{Српски/матерњи као посредни језик осталих предметних садржаја и CLIL метода}

Када се говори о настави српског језика у школском, образовном систему, сматра се да се она одвија само на часовима српског језика. На присутво српског као вехикуларног језика, језика посредника, језика на коме се одвија настава предметних садржаја који нису језички или књижевни, не обраћа се посебна пажња. У настави српског језика 
као језика окружења и образовања, српски као академски језик, језик посредник осталих предметних садржаја, и начин његовог посредовања међу којима се истиче CLIL приступ, имају кључну улогу.

Увођењем CLIL процедуре, осим свеобухватног доприноса побољшању сложеног система језичких знања, доприноси се и превазилажењу језичких, културних и комуникацијских баријера и развијању толеранције и уважавања, културне и цивилизацијске неограничености. Високи ниво интеркултурне толеранције и поштовање другог и различитог додатне су предности овог посебног приступа у учењу и настави страних језика. У вези са одабиром наставне методе стручњаци истичу да овакав облик наставе захтева друштвено-конструктиван приступ како би се ученику омогућио централни положај и активно учешће у процесу учења. Друштвено-конструктивни приступ подразумева интерактивну наставу између наставника и ученика, као и подршку у процесу учења коју ученику може пружити наставник, други ученик или неки трећи извор. Такође, у овом приступу је посебно наглашена посредничка улога наставника којом се ученику помаже у когнитивним подстицајима у оквиру појединачне зоне проксималног развоја. Наставников задатак се огледа у одржавању равнотеже између когнитивних подстицаја за ученике и подршке која се смањује са учениковим напредовањем.

\section{Закључак}

У сусрет изазовима подстакнутим савременим тренутком који подразумева неговање толеранције и интеркултурности кроз вишејезичност, укључивање стратешких компетенција за целоживотно учење које на првом месту постављају матерњи језик и стране језике, на основу горе наведених искустава развијених земаља и ставова изражених кроз сложене факторе избора страних језика и холистичко поимање језичког система у школи као основној јединици образовања, као успешан модел језичке образовне политике издваја се политика одоздо-на-горе. Овај начин стратешких одређења и одлучивања подразумева примену глобално познатих и признатих савремених те- 
оријских и прагматичних тековина заснованих на потребама, усклађеним са промовисањем специфичних ситуација локалног контекста, уз активно учешће локалних заједница и прихватање и препознавање потреба појединаца.

Оваква политика подразумева укључење шире палете страних, регионалних и мањинских језика на локалном и регионалном нивоу (уз системску припрему и подршку и акредитацију од стране релевантних институција) као и подршку формирању институционалног оквира који школама и локалним и регионалним заједницама омогућава формирање сопствених језичких образовних политика дефинисаних према потребама (одабир језика изван инстуционализованог оквира од понуђених, могућност увођења већег броја часова, и сл.)

Такође, политику одоздо-на-горе карактеришу већа могућност избора језика које ученик учи, разноврсност комбинација првог и другог страног језика у школама, ранији почетак и повећање фонда часова другог страног језика, уравнотежена понуда страних језика у стручним школама, омогућавање ученицима слободе избора и развијање језика струке и наставе за стицање међународних лиценци, интензивирање учења страних језика струке на универзитетима, отварање могућности за вишепредметне студије на факултетима који образују будуће наставнике, подршку научним истраживањима у области глотодидактике, уважавање резултата истраживања приликом доношења образовнополитичких одлука итд.

\section{Референце:}

Амон (2000): Ammon, U. Towards more Fairness in International English: Linguistic Rights of Non Native Speakers?, in R. Phillipson (ed.), Rights at Language. Equity, Rower, and Education. Celebrating the $60^{\text {th }}$ Birthday of Tove Skutnabb-Kangas, Lawrence Erlbaum Associates, Mahwah (NJ), str. 111-6.

Барозо et al (2008): Baroso, J. et al. Proposals from the group for intelectual Dialogue set up the Initiative of the European Comission "Rewarding challenge: How the multiplicity of languages could 
strengthen Europe", Brussels http://ec.europa.eu/education/policies/ lang/doc/maalouf/report_en.pdf, [08.10.2011. u 10.52]

Беако, Бајрам, Косте, Флеминг (2009): Beacco, J.С., Byram, M., Coste, D., Fleming, M.. A platform of resources and references for plurilingual and intercultural education, Language Policy Division, DG IV / EDU / LANG 2, [April 09], www.coe.int/lang[07.10.2011. u 21.43]

Волемер (2006): Vollemer, H. Language Across the Curriculum, Strasbourg.

Вучо (2009a): Vučo, J. Kako se učio jezik. Pogled u istoriju glotodidaktike od prapočetaka do Drugog svetskog rata. Beograd: Ministarstvo za nauku i zaštitu životne sredine i Filološki fakultet.

Вучо (2009b): Vučo J. La lingua per studiare - l'italiano e il serbo, Ur: Carla Marello e Elisa Corino, Scienza multlingue, Torino.

Вучо (2009c): Vučo J. Akademska kompetencija, jezik obrazovanja - srpski i italijanski, Srpski jezik u upotrebi. Ur: M. Kovačević, Filološko - umetnički fakultet, Kragujevac, 427 - 237.

Вучо, Ђурић, Крајишник, Стрижак, Сукновић, Филиповић (2018): Vučo, J., Đurić, Lj., Krajišnik, V., Strižak, N., Suknović, M., Filipović, J.. Od srpskog kao stranog jezika do srpskog kao jezika okruženja i obrazovanja: okvir programa jezičke podrške, Filološki fakultet Univerziteta u Beogradu, Beograd (uštampi).

Ди Перна, Елиот (1999): Di Perna, J. C., Elliott, S. N.. Development and validation of the Academic Competence Evaluation Scales. Journal of Psychoeducational Assessment, 17, 207-225.

Ђурић (2016): Đurić, Lj.. Strani jezici u obrazovnoj politici Srbije, Filološki fakultet, Beograd

Европска комисија (2017): European Comission/EACEA/Eurydice, Key Data on Teaching Languages at School in Europe - 2017 Edition. Eurydice Report. Luxembourg: Publications Office the European Union.

Зајдхофер (2003): Seidlhofer, B.. A concept of international English and related issues: From "real English" to "realistic English"? Strasbourg: Council of Europe, Language Policy Division Publication.

Каминс (1982): Cummins, J.. The role of primary language development in promoting educational success for language minority students. In Schooling and language minority students (pp. 3-49). Sacramento, CA: California Department of Education. 
Каминс (1991): Cummins, J.. Interdependence of first- and second-language proficiency in bilingual children. In E. Bialystok (Ed.), Language processing in bilingual children (pp. 70-89).Cambridge: Cambridge University Press.

Каминс (2010): Cummins, J.. Bilingual Children's Mother Tongue: Why Is It Important for Education? http://www.iteachilearn.com/cummins/ mother.htm, [10. 12. 2010, u 12.33].

Коксхед (2000): Coxhead, A. Academic Word List, (AWL) A New Academic Word List. TESOL Quarterly, 34(2): 213-238.

Калве (1999): Calvet, J. Pour une écologie des languages du monde, Plon, Paris. Кристал (1997): Crystal, D. English as a global language (2nd edition 2003). Cambridge. Cambridge.

Кристал (2000): Crystal, D. Language Death, Cambridge University Press, Cambridge-New York.

Кристал (2008): Crystal, D.. Two thousand million?, English today, 24 (1), March 2008, 00 3-6, Cambridge University Press.

Лазаревић (2011): Lazarević, R.. Uloga maternjeg jezika (L1) u nastavi italijanskog jezika na univerzitetu, u: J. Vučo, B. Milatović (ur.), Stavovi promjena-promjena stavova, Nikšić, Filozofski fakultet, 117-177.

Мејеркорд (1996): Meierkord, K. Englisch als Medium der interkulturellen Kommunikation. Untersuchungen zum non-native-/ non-native-speaker Diskurs. Frankfurt.

Mejep (2003): Mair, C. (Ed.). The politics of English as a world language: New horizons in postcolonial cultural studies. Amsterdam: Rodopi 2003.

Филиповић (2008): Filipović, J. Engleski kao lingua franca: koncept, karakteristike i implikacije za nastavu i evaluaciju, J. Vučo (ur.) Evaluacija u nastavi jezika i književnosti, Filozofski fakultet, Nikšić 2008 str. 289-302.

Филиповић (2009): Filipović, J.. Moć reči, ogledi iz kritičke sociolingvistike, Zadužbina Andrejević, Beograd

Филиповић, Вучо, Ђурић (2010): Filipović, J., Vučo, J., Đurić, Lj.. From Language Barriers to Social Capital: Serbian as the Language of Education for Romani Children, Selected Proceedings of the 2008 Second Language Research Forum: Exploring SLA Perspectives, Positions, and Practices, ur. Matthew T. Prior, Yukiko Watanabe, Sang-Ki Lee, vi+275 2010, Cascadilla Proceedings Project, Somerville, MA, USA, str. 261-275. 
Филиповић (2015): Filipović, J.. Transdisciplinary approach to language study. The complexity theory perspective. London: Palgrave Macmillan.

Филиповић, Дурбаба (2014): Филиповић, Ј. и Оливера Д. (eds.), Језици у образоваюу и језичке образовне йолитиике. Београд: Филолошки факултет, Универзитет у Београду, Чигоја.

Филиповић (2016): Filipović, J. Lingvistika i teorija kompleksnosti. jezičko liderstvo kao intergralni deo jezičke politike i planiranja u 21. veku. U: S. Gudurić \& M. Stefanović (ur.), Jezici i kulture u vremenu $i$ prostoru $V$. Novi Sad: Filozofski fakultet Univerziteta $\mathrm{u}$ Novom Sadu, str. 623-636.

Филиповић (2015): Filipović, J. Language education policies and foreign language teacher education: agencies, practices and perspectives. Filološki pregled/Revue de Philologie, XLII: 41-52.

Филиповић (2012): Filipović, J. Language policy and planning from the complexity perspective. In: Julijana Vučo \& Jelena Filipović (eds.) Filološka istraživanja danas. Jezik i društvo. Filološki fakultet Univerziteta u Beogradu, pp. 285-320.

Филиповић, Вучо (2012): Filipović, J., Vučo, J.. Language policy and planning in Serbia: language management and language leadership. Anali Filološkog fakulteta, 24(II): 9-32.

Фишман (1976): Fishman, J.. Bilingual Education. An International Sociological Perspective, Newbury House, Rowley, Massachusetts 1976.

Фишман (1999): Fishman, J.. Handbook of Language and Ethnic Identity, Oxford University Press.

Този (2007): Tosi, A. Un italiano per l'Europa, Carocci, Roma.

Џенкинс (1998): Jenkins, J.. Which pronunciation norms and models for English as an international language. ELT Journal 52/2: 119-126.

Џенкинс (2000): Jenkins, J. The Phonology of English as an International Language. Oxford: OUP

Џенкинс (2001): Jenkins, J.. Euro-English: "Euro-English accents”. English Today, 68/17 (4): 16-18.

Шлепегрел (2004): Schleppegrell, M. The language of schooling: A functional linguistics perspective, Volume 8, Number 2, Mahwah, New Jersey: Lawrence Erlbaum Associates.

Шорт, Спанос (1989): Short, D. J. \& Spanos G., "Teaching mathematics to limited English proficient students". ERIC Digest. Washington, DC. 


\section{Сајтографија}

Линк 1. Lotten, Mona (Ed.) Languages for the Future, Which languages the UK needs most and why, British Council, 2014. https://www. britishcouncil.org/sites/default/files/languages-for-the-futurereport-v3.pdf, приступљено 22. јануара 2018.

Линк 2. Assembly debate on 28 September 2001 (32nd Sitting) (see Doc. 9194, report of the Committee on Culture, Science and Education, rapporteur: Mr Legendre. Text adopted by the Assembly on 28 September 2001 (32nd Sitting)http://assembly.coe.int/nw/xml/XRef/ Xref-XML2HTML-en.asp?fileid=16954\&lang=en, приступљено 27. јануара 2018.

Линк 3. Europeans and their Languages Fieldwork: November December 2005 Publication: February 2006, Special Eurobarometer, 243 / Wave 64.3 - TNS Opinion \& Social European Commission http://ec.europa.eu/commfrontoffice/publicopinion/archives/ebs/ ebs_243_sum_en.pdf, приступљено 22. јануара 2018.

Линк 4. Lifelong learning - key competences, Recommendation 2006/962/ EC of the European Parliament and of the Council of 18 December 2006 on key competences for lifelong learning (OJ L 394, 30.12.2006, pp. 10-18)http://eur-lex.europa.eu/legal-content/EN/ AUTO/?uri=celex:32006H0962, приступљено 22. јануара 2018. 


\title{
Julijana Vučo
}

\section{LANGUAGES AND LANGUAGES OF SCHOOLING}

\begin{abstract}
Summary
Contemporary language policies promote new insights into the importance of languages in educational systems, and they argue for of multilingual teaching as a promoted approach. Serbian, for example, is considered only as a school subject and a linguistic system, rather than an overarching concept of language of education, necessary for achieving general academic competences in light of the fact that the highest percentage of teaching in all other subjects in the school system takes place precisely in Serbian. Also, teaching of foreign languages is not viewed as a grounds for the development of a set of common competences that contribute to the enrichment of both encyclopedic knowledge and of a language understood as an instrument of individual expression. These and other language functions equally participate in the formation of the language of education as an integral component, constitute the language of everyday communication and contribute to the development of specific academic competences.

In this paper, globalization processes and specificities of European language policies that should be reflected in linguistic education policies of a modern multilingual society are investigated, and the the importance of language in contemporary education systems is emphasized, which is based on the a need to create a bottom-up language education policy which would recognize language needs of local communities and help them become mapped globally.
\end{abstract}

Key words: language policies, language and educational systems, language and languages of education, foreign language, second foreign language. 